\title{
A Hedonic Analysis of the Impact of Marine Aquaculture on Coastal Housing Prices in Maine
}

\author{
Keith S. Evans, Xuan Chen, and Christina A. Robichaud
}

\begin{abstract}
Converting coastal waters to farmed production of seafood may generate conflicts with other resource users. This study explores the impact of marine aquaculture development on coastal homeowners. Using single-family home sales from 20122014 and spatial data on coastal aquaculture activity, we employ hedonics to assess the impacts of mariculture development in three study areas of Maine, USA. Our results suggest modest impacts on residential property values with significant spatial variation across study areas. This spatial variation represents a challenge for managers and highlights the potential benefits from coordinating the development of aquaculture to balance resource users' objectives with industry growth.
\end{abstract}

Key Words: coastal waters, hedonic pricing model, marine aquaculture, mariculture, property values

Aquaculture is an important source of fish protein. While wild-capture production has flat-lined since the mid-1980s, due to excessive fishing pressure and changing ocean conditions, world production from aquaculture has grown exponentially to meet market demand (World Bank 2013, Food and Agriculture Organization of the United Nations (FAO) 2016). Although China has represented the majority of this growth, generating more than 60 percent of production by volume (FAO 2016), early research suggests that a wide-range of marine production opportunities exist for the United States (Knapp 2008, Valderrama and Anderson 2008, Kite-Powell, Rubino, and

Keith Evans is an Assistant Professor in the School of Economics and School of Marine Sciences, University of Maine, Orono, ME 04469. Xuan Chen is an Assistant Professor in the School of Economics, University of Maine, Orono, ME 04469. Christina Robichaud is a graduate student in the School of Economics, University of Maine, Orono, ME 04469. Correspondence: Keith S. Evans - School of Economics - 5782 Winslow Hall, Room 206 - Orono, ME 04469 - Phone 207.581.3178 . email: keith.evans@maine.edu.

The authors thank Maine Multiple Listings Service for providing access to the sales transactions data. We would also like to thank the participants at the 2016 NAREA workshop and two anonymous reviewers for helpful suggestions. This project was supported by the National Science Foundation under EPSCoR award \#IIA-1355457 and the USDA National Institute of Food and Agriculture under Hatch projects \#ME021603 and \#ME021704.

The views expressed are the authors' and do not necessarily represent the policies or views of any sponsoring agencies.

Agricultural and Resource Economics Review 46/2 (August 2017) 242-267

(C) The Author(s) 2017. This is an Open Access article, distributed under the terms of the Creative

Commons Attribution licence (http://creativecommons.org/licenses/by/4.0/), which permits unrestricted re-use, distribution, and reproduction in any medium, provided the original work is 
Morehead 2013). Recent work by Kapetsky, Aguilar-Manjarrez, and Jenness (2013) ranks the United States as one of the top countries with potential for profitable expansion of marine aquaculture, known as mariculture. Beyond profit opportunities, increasing aquaculture production in the United States can help reduce the U.S. seafood trade deficit, which has grown to over $\$ 14.5$ billion annually (National Oceanic and Atmospheric Administration (NOAA) 2015), and create healthier oceans by reducing fishing pressure on wildstocks, providing habitat, and species restoration (Knapp and Rubino 2016, NOAA 2016a). ${ }^{1}$ These opportunities have not been lost on U.S. policy makers. In 2016, NOAA released its strategic plan for offshore aquaculture, calling for a 50 percent increase in production by volume in the United States by 2020 (NOAA 2016b). Even at state and local levels, there has been interest in increasing aquaculture production and coastal development: promoting working waterfronts, providing alternate local marine employment opportunities, and diversifying against uncertainty for struggling wild-capture fisheries and resource-dependent coastal communities (Governor's Task Force on the Planning and Development of Marine Aquaculture in Maine 2004, Lapointe 2013, Knapp and Rubino 2016, Sustainable Ecological Aquaculture Network 2016). Together, this suggests a broad interest among policy makers for the large-scale, nonmarginal development of marine aquaculture in the United States.

Despite interest in expanding coastal aquaculture among U.S. policy makers, Knapp and Rubino (2016) and Knapp (2012) highlight challenges facing its development. Marine aquaculture generates interactions with other coastal and marine resource users. Converting public waters to the farmed production of seafood alters the mixture of goods and services that coastal ecosystems provide, thereby generating a new distribution of winners and losers among resource users. The dual nature of externalities related to mariculture further complicates coastal development and siting decisions (Bhat and Bhatta 2004, Primavera 2006, Whitmarsh and Palmieri 2008); externalities are generated by coastal activity and users (on aquaculture) and from the production of aquaculture itself (on coastal activity and users). Knapp and Rubino (2016) note that some users in this system, e.g., riparian homeowners, recreationists, and commercial fishermen, may fear that the potential negative impacts of marine aquaculture may not be offset by private benefits. Bricknell and Langston (2013) suggest that researchers and the aquaculture industry have failed to effectively communicate the positive benefits of aquaculture. These tensions or perceptions of risk may emerge at public lease hearings and through interactions in coastal real-estate markets; property values may be influenced by proximity to aquaculture as it alters viewscape and/or generates smell and noise.

\footnotetext{
1 Of course, some of these benefits may be mitigated by substitution of fishing pressure onto prey species for carnivorous farmed-fish (e.g., salmon).
} 
Addressing these challenges is a priority for policy makers and researchers. Goal 4 of NOAA's strategic plan aims to increase/improve public understanding of marine aquaculture production to reduce barriers to its development (Knapp and Rubino 2016, NOAA 2016b). Stakeholders, especially those interested in the resiliency of coastal communities, are interested in the potential risks and benefits of mariculture, evaluated through the lenses of multiple disciplines (NOAA 2016b). A better understanding of the impact of developing coastal mariculture on riparian homeowners and other resource users is important for managers interested in promoting the long-run health of this emerging industry.

Work to date has focused on describing coastal residents' perceptions of marine aquaculture (Mazur and Curtis 2008, Schlag 2010, McGinnis and Collins 2013, D'Anna and Murray 2015). Shafer, Inglis, and Martin (2010) explore these perceptions surrounding proposed marine farms on the Banks Peninsula, New Zealand. Their results suggest that proximity of marine development to residents is an important factor influencing acceptance. Residents living closer to the proposed marine farms were more sensitive to marine development and less accepting of them, despite acknowledging the potential economic benefits to the local community. This is consistent with the idea that marine aquaculture may be considered a locally undesirable marine use. Efforts to quantify the impacts of mariculture and marine development are limited (Jodice et al. 2015). Two examples related to aquaculture are worth noting: first, an unpublished dissertation by Sudhakaran (2015), which finds minimal impacts of shellfish aquaculture on coastal property values in Rhode Island, USA; second, a technical memorandum from Northern Economics (2010), which outlines a method for a hedonic analysis of the impact of commercial shellfish operations in Puget Sound, Washington, USA. However, as far as the authors can tell, the empirical analysis was never published; nor has any other hedonic analysis of mariculture. ${ }^{2}$

In this paper, we use a semiflexible form hedonic pricing model to quantify the impacts of coastal mariculture development on residential property values in Maine; we use three coastal regions along Maine's coastline as our study setting. We incorporate spatial information surrounding marine aquaculture to explore two main research questions: (i) does marine

\footnotetext{
2 In the related industry of agriculture, economists have used the hedonic pricing model to explore the impacts of agriculture production on nearby residential properties (Abeles-Allison and Connor 1990, Palmquist, Roka, and Vukina 1997, Herriges, Secchi, and Babcock 2005, Kim and Goldsmith 2009). This body of work suggests that the impact of agriculture on residential properties may be complex, depending on more than proximity. For example, Ready and Abdalla (2005) find potentially offsetting positive/negative impacts of farming activity near residential property values; living near livestock farms may reduce residential property values, while the open spaces associated with these farms may have the opposite effect. Le Goffe (2000) and others find similar results.
} 
aquaculture capitalize into residential property values, and, if so, (ii) how does this vary based on the spatial arrangement of leases (e.g., density of leases, acreage of leases, proximity to residential properties). To this end we collect transactions data (i.e., structural and neighborhood characteristics) for singlefamily homes sold in Maine from 2012-2014. These data are combined with historical, spatial information on aquaculture production and leases issued in Maine between 1981 and 2014, and localized information on attitudes toward coastal development of aquaculture contained in transcripts from public aquaculture lease hearings.

Our results suggest wide variation in how marine development of aquaculture impacts property values, and therefore implicitly reveals insights into local residents' perceptions of marine aquaculture - as a coastal amenity or disamenity. This spatial variation presents interesting challenges for coastal resource managers, especially those at state and federal levels. It also highlights the potential benefits from coordinating aquaculture site choices designed to balance the competing objectives of diverse groups of coastal resource users. This information is especially relevant when considering future development of aquaculture in these shared waters. Resource planners must evaluate whether smaller farms or large-scale industrial farms are more appropriate for the cultural and ecological capacity of the coastal waters. To answer such questions, the information on preferences from multiple groups of users is critically important. Results of our hedonic pricing model help fill knowledge gaps for these managers, providing information on preferences of one group of users (coastal residents) surrounding aquaculture development in coastal waters.

\section{Background}

Maine is one of the top marine producers of aquaculture in the United States, with a farm-gate value in excess of $\$ 100$ million (Maine Aquaculture Association (MAA) 2015). With more than 5,000 miles of coastline, marine farms in Maine produce an impressive variety of species, such as salmon, cod, oysters, scallops, and sea vegetables (e.g., dulse and sugar kelp), using leases on only 0.03 percent of the state's public waters (MAA 2015, Maine Department of Marine Resources (DMR) 2016). Management of aquaculture in these coastal waters is divided between two state agencies: the Maine DMR and the Maine Department of Environmental Protection (DEP). While the Maine DEP is charged with ensuring that marine farms satisfy the discharge standards specified under the Clean Water Act, the Maine DMR is responsible for issuing aquaculture leases (East Coast Environmental Law 2014), and indirectly monitoring the development of marine aquaculture in the state.

Much of the coastal development in Maine has occurred over the last 30 years, as regulations streamlined the licensing process and lessened challenges involved with monitoring water quality. Prior to 1973, marine farmers in 
Maine were not guaranteed legal protection for their product (Maine DMR 2012). In 1983, Maine implemented Maine Revised Statutes Annotated (MRSA) 12, Chapter 2, which defined the aquaculture lease regulations that are in effect today, specifying the rights and legal protections of lease holders (MRSA 2013). Under the current aquaculture leasing system, there are two types of aquaculture leases and one type of license that provide an aquaculturist with rights to grow in the state's public waters: a standard lease, an experimental lease, and a limited-purpose aquaculture (LPA) license. Each type of lease/license specifies slightly different rights to its holder. These rights specify which marine species can be grown, the duration and renewability of the lease/license, etc. The major difference between lease/license types in our analysis centers around the maximum acreage of coastal waters that can be allocated to an individual for farming marine species. Table 1 outlines some of the differences between lease and license types.

The siting of marine farms in Maine is largely decentralized - affecting the spatial pattern of coastal development. Unlike some U.S. states that use marine aquaculture zones for siting leases in predefined growing areas (for example, Aquaculture Enterprise Zones in Chesapeake Bay, Maryland, USA (Maryland Natural Resource Code §4-11A-05 (2015)), in Maine, the initial siting choice is made by the applicant. The final decision regarding issuing this lease or license rests with the Maine DMR Commissioner. As part of the application process, riparian landowners are notified if a proposed lease is within 1,000 feet of their property (300 feet for LPAs), while the general public is informed through public notices issued in the local newspaper and the Maine DMR website. Proposed sites may draw considerable attention in an area depending on its history with aquaculture (see Graves (2016) and

Table 1. Maine Aquaculture Lease and License Characteristics. Information from Maine DMR (2012) and Maine Revised Statutes Annotated 12, Chapter 2 (2013).

\begin{tabular}{lllllll}
\hline $\begin{array}{l}\text { Lease/ } \\
\text { license type }\end{array}$ & $\begin{array}{l}\text { Notice } \\
\text { distance }\end{array}$ & $\begin{array}{l}\text { Scoping } \\
\text { session }\end{array}$ & $\begin{array}{l}\text { Public } \\
\text { hearing }\end{array}$ & Size limit & Duration & Renewal \\
\hline $\begin{array}{c}\text { Standard } \\
\text { lease }\end{array}$ & 1,000 feet & Yes & Yes & $\leq 100$ acres & 10 years & Yes \\
$\begin{array}{c}\text { Experimental } \\
\text { lease }\end{array}$ & 1,000 feet & Maybe $^{\dagger}$ & Maybe $^{\dagger \dagger}$ & $\leq 10$ acres & $1-3$ years & No $^{\dagger+\dagger}$ \\
$\begin{array}{c}\text { Limited } \\
\text { purpose } \\
\text { license }\end{array}$ & 300 feet & No & No & $\leq 400$ sq ft & $\begin{array}{c}\text { Calendar } \\
\text { year }\end{array}$ & Yes \\
\hline
\end{tabular}

${ }^{\dagger}$ Scoping sessions are at the discretion of the Maine DMR.

${ }^{+\dagger}$ Yes, if five or more comments are raised during the public comment period, or the Maine DMR requests a hearing.

${ }^{+\dagger \dagger}$ Renewable if experimental lease is designated for research purposes. 
Mitterhoff (2016) for examples). Public comment periods and lease hearings (town hall meetings) provide opportunities for other coastal users to give testimony and raise concerns about the effects of siting aquaculture in their community. Testimony at these meetings is restricted to the objective criteria that the Maine DMR uses to evaluate a lease application; subjective issues related to the lease (e.g., change in viewscape and effects on property values) are beyond the scope of these criteria and generally do not effect the final lease approval decision. Under the Maine DMR criteria, a lease may not "unreasonably interfere" with riparian owners' land access, navigation, fishing or other uses, support of ecologically significant flora and fauna, or public use or enjoyment within 1,000 feet of government managed or conserved beaches, parks, docks, and land, and cannot have an "unreasonable impact" due to noise or light (Maine DMR n.d.).

Our analysis focuses on the effects of marine aquaculture on the value of single-family homes in three study areas along Maine's coastline: Casco Bay, the Damariscotta River region, and Penobscot Bay (Figure 1). Each study area

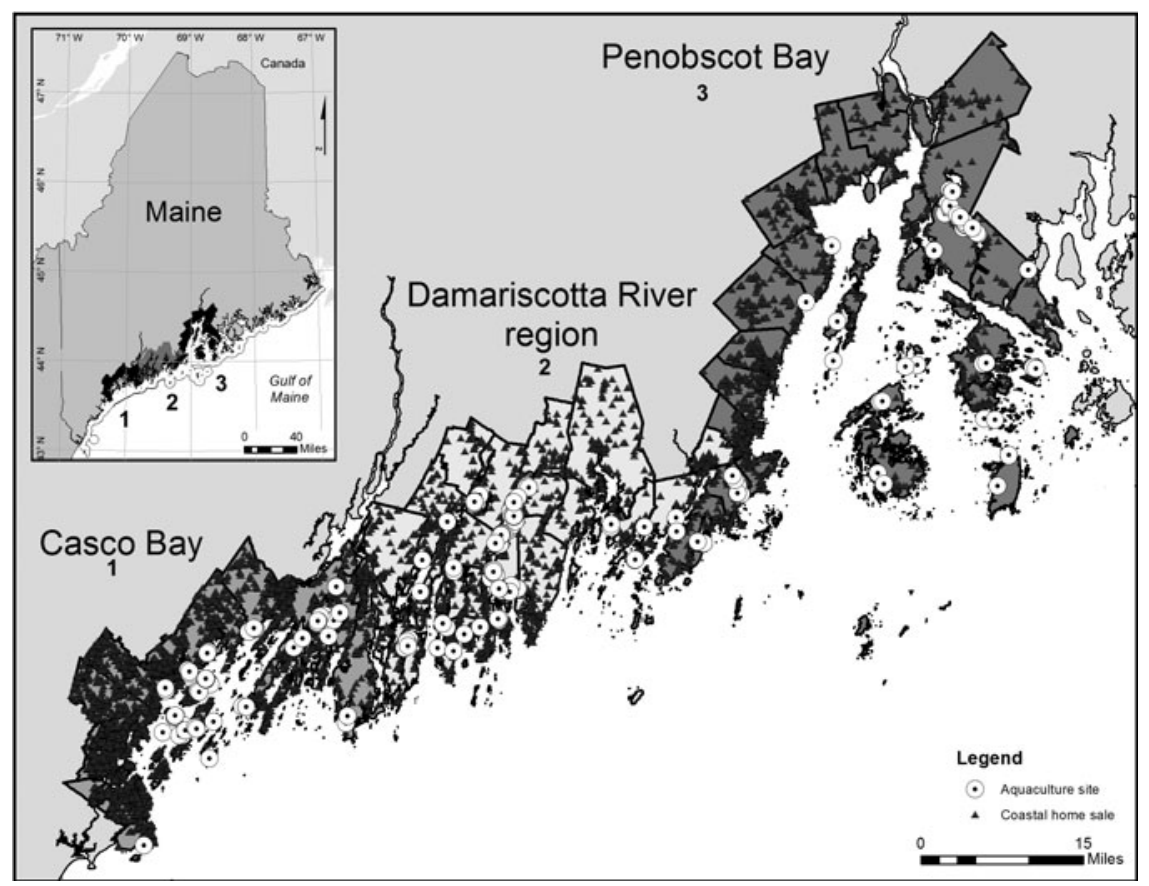

Figure 1. Casco Bay, Damariscotta River Region and Penobscot Bay. Inset panel: Location of study areas along the Maine coastline. Greater panel: Housing transactions of single-family homes sold between January 2012 and December 2014 (black triangles) and corresponding aquaculture leases (circled dots) in the three study areas. 
contains the municipalities designated as coastal by the Maine Coastal Program (Maine Coastal Program 2013). These study areas provide useful focal points and comparisons for our analysis. Their coastal waters vary in how they provide important employment opportunities in wild-capture fisheries (e.g., lobster and soft-shell clams), whether or not they are popular areas for recreation and tourism, and in the opportunities they provide for coastal development of marine aquaculture.

There is considerable variation across these study areas with their connection to their coastal waters. Penobscot Bay, located northeast of the other study areas, is dominated by ecotourism and generates its wealth from the "natural" environment. Alternatively, Casco Bay represents a heavily urban region of Maine, containing two of the largest cities in the state, whose waterfronts support shipping, recreation, and commercial fishing. Finally, the Damariscotta River region, sandwiched between Casco Bay and Penobscot Bay, has a long history of promoting development of marine aquaculture. It contains almost 200 acres of coastal water designated for marine aquaculture and produces more than 80 percent of the oysters grown in Maine (Damariscotta River Association 2016). In addition to highlighting the competing uses in these shared coastal waters, these study areas are data rich, containing almost 200 lease sites (producing shellfish and sea vegetables) and 8,500 transactions of single-family homes during 2012-2014.

\section{Methods}

\section{Statistical Model}

The hedonic pricing model, formalized by Griliches (1971) and Rosen (1974), is a well-established method for eliciting nonmarket values for environmental attributes connected with residential properties. This model posits that the sales price for a home represents the equilibrium value for its bundle of attributes. These attributes extend beyond the structural characteristics of the property $S$ (e.g., living space, bathrooms, and lot size), to also include characteristics of the neighborhood in which the house is located $N$ (e.g., local school quality and crime rate) and localized environmental conditions $Q$ (e.g., viewscape and air quality). Buyers and sellers compete across these attributes generating the sales price for a home. The hedonic pricing function describes this equilibrium relationship, mapping the attributes of home $i$ in neighborhood $j$ at date $t$ to its transaction price $P_{i j t}$,

$$
P_{i j t}=f\left(S_{i}, N_{i j}, Q_{i}\right)+\varepsilon_{i j t}
$$

where $\varepsilon_{i j t}$ is a random error term. Variation in housing attributes and prices, contained in observed transactions, can be used to recover information about this unknown function. 
The implicit marginal price for an attribute, or marginal willingness-to-pay (MWTP), can be recovered as the slope of $f(\cdot)$. A positive (negative) value suggests that homeowners perceive this attribute as an amenity (disamenity), on the margin. This approach has been used in a variety of empirical settings to recover the MWTP for environmental attributes, such as water quality (Michael, Boyle, and Bouchard 2000, Gibbs et al. 2002, Poor, Pessagno, and Paul 2007), dam removal (Lewis, Bohlen, and Wilson 2008, Bohlen and Lewis, 2009), and proximity to hydraulic fracturing well sites (Gopalakrishnan and Klaiber 2014, Muehlenbachs, Spiller, and Timmins 2015). In this paper, we will use this method to explore the effects of mariculture in coastal waters.

Because $f(\cdot)$ has an unknown form, we employ a Box-Cox transformation on sales price to incorporate flexibility in our selection of functional form (Box and Cox 1964). Standard specifications, such as linear $(\lambda=1)$, log-linear $(\lambda=0)$, and reciprocal $(\lambda=-1)$, are special cases of the Box-Cox specification and are tested during the estimation process. Let $P^{(\lambda)}$ denote the Box-Cox transformed sales price where

$$
P^{(\lambda)}= \begin{cases}\frac{P^{\lambda}-1}{\lambda} & \text { if } \lambda \neq 0 \\ \log P & \text { if } \lambda=0 .\end{cases}
$$

We model the transformed sales price of home $i$ in municipality $j$ in year $t$ as a linear function of local conditions and an additive error term $\epsilon_{i j t}$,

$$
P_{i j t}^{(\lambda)}=\beta_{0}+\beta_{1} S_{i}+\beta_{2} N_{i j}+\beta_{3} Q_{i}+\delta_{i}+\delta_{j}+\epsilon_{i j t}
$$

where $\delta_{j}$ and $\delta_{t}$ are location (municipality) and sales-year fixed effects, and $\beta_{m}$ captures the marginal influence of housing attribute $m$ on the transformed transaction price.

\section{Data}

\section{Housing Transactions}

Housing transaction data were obtained from Maine Multiple Listings Service (MLS), a private company maintaining a near-complete database of real estate information for realtors. These data span January 2012 through December 2014 and contain a complete set of structural characteristics, sale and location information for all single-family detached homes sold in Maine. After removing transactions with missing information (i.e., sale or structural characteristics), our sample consists of 5,698, 1,238 and 1,644 housing transactions for the Casco Bay, Damariscotta River and Penobscot Bay regions. Table 2 provides summary statistics for these attributes by study area. 
Table 2. Sample Summary Statistics. Housing transactions data spans January 2012 through December 2014 and contains all single-family detached homes sold in Maine. Coastal aquaculture activity data includes all active leases issued by the Maine DMR over the same study period.

\begin{tabular}{|c|c|c|c|c|c|c|}
\hline \multirow[b]{3}{*}{ Home characteristics } & \multirow{2}{*}{\multicolumn{2}{|c|}{$\frac{\text { Casco Bay }}{(N=5,698)}$}} & \multirow{2}{*}{\multicolumn{2}{|c|}{$\begin{array}{l}\text { Damariscotta } \\
(\mathrm{N}=1,238)\end{array}$}} & \multirow{2}{*}{\multicolumn{2}{|c|}{$\frac{\text { Penobscot Bay }}{(N=1,644)}$}} \\
\hline & & & & & & \\
\hline & Mean & Std. Dev. & Mean & Std. Dev. & Mean & Std. Dev. \\
\hline Sales price $(\$ 1,000 \mathrm{~s})$ & 327.84 & 288.32 & 292.13 & 283.92 & 273.19 & 318.04 \\
\hline Lot size (acres) & 1.11 & 4.90 & 3.80 & 9.40 & 3.10 & 7.20 \\
\hline $\begin{array}{l}\text { Living area (100s } \\
\text { square feet) }\end{array}$ & 2.04 & 1.01 & 1.89 & 0.97 & 1.91 & 1.11 \\
\hline Bathrooms & 1.73 & 0.84 & 1.70 & 0.91 & 1.70 & 0.94 \\
\hline Age (years) & 63.22 & 89.34 & 76.36 & 132.38 & 79.51 & 127.51 \\
\hline Cabin $(0 / 1)$ & 0.01 & 0.08 & 0.02 & 0.13 & 0.02 & 0.14 \\
\hline $\begin{array}{l}\text { Distance to water } \\
\text { (miles) }\end{array}$ & 0.99 & 1.28 & 0.67 & 1.10 & 0.86 & 1.24 \\
\hline $\begin{array}{l}\text { Homes with aquaculture } \\
\text { (2-mile) }\end{array}$ & $13.97 \%$ & & $46.04 \%$ & & $14.77 \%$ & \\
\hline $\begin{array}{l}\text { Coastal aquaculture } \\
\text { activity }\end{array}$ & Count & Acres $^{\dagger}$ & Count & Acres $^{\dagger}$ & Count & Acres $^{\dagger}$ \\
\hline Standard lease & 9 & 46.08 & 41 & 196.71 & 20 & 95.90 \\
\hline Experimental lease & 8 & 24.86 & 6 & 2.18 & 7 & 8.03 \\
\hline $\begin{array}{l}\text { Limited purpose } \\
\text { aquaculture }\end{array}$ & 57 & 0.52 & 77 & 0.71 & 59 & 0.54 \\
\hline Public lease hearings & Count & Mean & Count & Mean & Count & Mean \\
\hline Lease hearings & 6 & - & 22 & - & 10 & - \\
\hline Concerns (all) ${ }^{\dagger \dagger}$ & 25 & 4.17 & 62 & 2.82 & 75 & 7.50 \\
\hline $\begin{array}{l}\text { Concerns (to riparian } \\
\text { users) }^{+t \dagger}\end{array}$ & 15 & 2.50 & 54 & 2.45 & 63 & 6.30 \\
\hline \multicolumn{7}{|c|}{ Transactions by sale year (counts) } \\
\hline 2012 & 1,641 & & 359 & & 492 & \\
\hline 2013 & 1,963 & & 436 & & 575 & \\
\hline 2014 & 2,094 & & 443 & & 577 & \\
\hline
\end{tabular}

${ }^{\dagger}$ Total number of acres in region.

${ }^{+\dagger}$ Any recorded concern raised at the public lease hearing (e.g., access to broodstock or smell).

${ }^{++\dagger}$ Concerns raised at public lease hearings specific to the impacts on riparian homeowners and coastal users (e.g., property values and change in viewscape). 
Transactions were geocoded using ArcGIS 10.3.1. Addresses were imported into ArcMap and matched to road files obtained from the Maine Office of GIS using the automatic match function. Unmatched addresses were manually assigned using the best approximate location and cross-referenced using Google maps.

Geocoded addresses were used to calculate spatial information related to home sales and connect these transactions to coastal aquaculture activity. Of particular importance was the location of a home in relation to coastal waters. For example, living close to water is generally viewed as an amenity, enhancing the value of the property. However, coastal aquaculture, necessarily, takes place in coastal waters as well. Omitting this spatial information will likely generate a positive bias on our estimate of the impact of mariculture on residential property values. To this end, we calculated the minimum distance from the home to the coastline and the percentage of water within a buffer zone centered on the home. The percentage of water acts as a proxy representing the view of the water for the home: a larger percentage is suggestive of increased view of the water or waterfront property. In addition, we also generated a dummy variable capturing whether or not a home was within 1,000 feet of a government managed or conserved beach, dock, park or land. Given the regulations on siting, being close to these structures limits marine development near the home and may provide access to additional amenities. ${ }^{3}$ Finally, we also included the elevation of the home to proxy for other possible view effects.

Additional spatial information was collected to control for neighborhood characteristics. While output-based measures are preferred (e.g., performance of students on standardized tests), small populations throughout portions of Maine limited data availability. Instead, expenditures per student for the 2014-2015 academic year was collected for each school district from the Maine Department of Education to proxy for school quality. School quality data were augmented with spatial information on the proportion of seasonal housing units and median household income by census tract obtained from the 2012, 2013 and 2014 estimates of the American Community Survey.

\section{Coastal Aquaculture Activity}

Historical spatial information on aquaculture leases in Maine, spanning 1981 through 2014, was obtained from the Maine Office of GIS. This data set contains information on aquaculture leases, including data on location (i.e., shape of the lease, latitude, and longitude), scale of production (acreage),

\footnotetext{
3 The authors recognize that if there are omitted housing attributes that increase/decrease the likelihood of aquaculture being sited near a home then this will introduce an endogeneity bias. Repeat sales data, capturing sales prices before and after the siting of aquaculture, could be used to explore this issue further.
} 
target species (i.e., shellfish and sea vegetables), and lease type (i.e., standard, experimental or LPA). ${ }^{4}$ These spatial data were linked to housing transactions to capture information on coastal aquaculture production in relation to residential homeowners.

To quantify the effects of coastal mariculture, we needed to incorporate this information into the econometric model. One complication is that homes face unique spatial arrangements of leases, such as different numbers of leases at different distances with different scales of production. To capture the various configurations, we generated an Aquaculture index variable $Q_{i}$, which combines this information to create a house-specific measure of aquaculture. The form of this index was based on past research and intuition. Previous literature suggests that homeowners prefer that aquaculture is sited further from their home (Shafer, Inglis, and Martin 2010), but that these effects may diminish nonlinearly with distance. Similarly, larger (and more) leases may correspond with a larger visual impact (obscured and/or splintered viewscape), potentially exacerbating issues of smell and noise, among other types of concerns.

We explore two alternate forms for this index, to capture the density (number of leases, $K_{i}$ ), scale (acreage, $a_{i k}$ ), and proximity (distance, $d_{i k}$ ) of aquaculture sited near home $i$ : a base case where $Q_{i}$ is defined as

$$
\text { Base: } \quad Q_{i}=K_{i} \sum_{k \in A_{i}} \frac{a_{i k}}{d_{i k}}
$$

where $A_{i}$ denotes the set of active leases associated with home $i$ at the time of sale, and an alternate index that scales $Q_{i}$ by the portion of water contained within a buffer zone $w_{i}$.

$$
\text { Alternate: } \quad Q_{i}=w_{i} \times K_{i} \sum_{k \in A_{i}} \frac{a_{i k}}{d_{i k}}
$$

We hypothesize that the percentage of water within the buffer zone is linked to the potential visibility of aquaculture production activity. Our indices are similar in form to those used to explore the impact of hydraulic fracturing wells (McCluskey and Rausser 2001, Gopalakrishnan and Klaiber 2014), but allow more variation in spatial arrangements of leases. ${ }^{5}$

\footnotetext{
4 Data on finfish leases in Maine are also available. However, aquaculture production in our study areas is exclusively shellfish and sea vegetables.

5 Alternative constructions of the index, e.g., separating by lease type, did not qualitatively change the results.
} 
We use buffer zones, centered around each home, to define the spatial extent of impacts from coastal aquaculture and thereby the set of leases associated with each home, $A_{i}$. This approach is commonly used in the literature (Lewis, Bohlen, and Wilson 2008, Gopalakrishnan and Klaiber 2014, Muehlenbachs, Spiller, and Timmins 2015). Any lease/license outside this set is assumed to have a negligible impact on the sales price of a home. We use an AIC statistic to explore four potential radius distances for these buffer zones: $0.5,1,1.5$, and 2 miles. Our upper bound of 2 miles was selected through a mixture of stakeholder feedback (aquaculturists, residents, and marine managers), previous research in other settings, and the physical constraints of seeing these marine structures (which for shellfish and sea vegetables are approximately one foot above the surface of the water). ${ }^{6}$ Across all study areas and models, a 2-mile radius distance was preferred (smallest AIC value).

Spatial data on leases were supplemented with qualitative information surrounding public lease hearings. The leasing process in Maine falls under the Administrative Procedures Act (APA) and requires public comments; all standard leases (and some experimental leases) require public hearings (Gericke and Sullivan 1994, MRSA 2013). Public aquaculture hearings offer the public (e.g., riparian landowners, municipalities, interested government agencies, and other interested parties) an opportunity to raise concerns about the impacts of aquaculture in local waters. These hearings are advertised 30 days prior in local newspapers and on the Maine DMR website, and serve as an opportunity for resource users to raise concerns about changes in the use of coastal waters surrounding the lease. Information from these lease hearings often are released in local newspapers, with more contentious hearings receiving additional print space (for example: Graves (2016) and Mitterhoff (2016)).

Concerns raised at these hearings tend to be specific to the lease and focus on localized changes in aesthetics and property values, and impacts on riparian access, navigation, and fishing. This is in sharp contrast with the broad concerns raised by the U.S. public toward aquaculture in general, which focus on the effects on human health and the environment, the welfare of fish, and a lack of regulatory structure and oversight (Schlag 2010, Claret et al. 2014). Lease hearing information on localized attitudes (i.e., the subjective information outside the criteria issued by the Maine DMR in the siting decision) generally does not affect the leasing outcome and is therefore treated as exogenous to siting decisions.

Hearing transcripts obtained from the Maine DMR were coded for the frequency and type of concerns raised about each lease. These concerns were

\footnotetext{
6 These distances are within the range of those used in previous literature such as Lewis, Bohlen, and Wilson (2008) , Gopalakrishnan and Klaiber (2014), and Muehlenbachs, Spiller, and Timmins (2015) to identify localized environmental effects. Supplemental material contains a table of distances and approaches used in other hedonic studies.
} 
coded into five categories: public use and enjoyment (e.g., smell, noise, visual impact, and property values), environmental impacts (e.g., water quality, flora and fauna), conflicts with commercial fisheries, legal concerns with the lease process, and practical concerns surrounding the lessee's competency. Separating comments from the public lease hearings into categories allowed us to focus on the concerns most tightly connected with riparian homeowners and housing prices. We focused on the information contained in two categories: concerns about public use and enjoyment, explicitly including property values and environmental impacts, for which a long literature in environmental economics suggests should affect property values. We combined this information to generate house-specific localized attitudes toward aquaculture located in their coastal waters, labeled Neighborhood attitudes $\left(N A_{i}\right)$ in our model. We interpret this combined set of concerns as capturing the perceived effects of aquaculture on riparian homeowners and coastal users. Neighborhood attitudes are calculated as the time-weighted average number of concerns about the effects of aquaculture on riparian and coastal users (e.g., public use and enjoyment and environmental impacts) raised at public aquaculture lease hearings. Let

$$
N A_{i}=\frac{1}{K_{i}} \sum_{k \in A_{i}} \frac{C_{k}}{1+t_{k}}
$$

where $C_{k}$ denotes the number of concerns raised about lease $k$ and $t_{k}$ denote the number of years between lease hearing and the sale year of the home. We constrain the set of leases $A_{i}$ used in the calculation of Neighborhood attitudes to those that were active (in the water) when home $i$ was sold. We utilize a hyperbolic time-weighting function to place more weight on recent information about local attitudes and significantly less weight on past information. Alternate time-weighting functions were evaluated (i.e., equal and linear time weighting) but had no qualitative effect on the results.

\section{Decomposition of Marginal Effects}

Our first research objective is to evaluate whether or not marine aquaculture capitalizes into residential property values. Given the Box-Cox specification for our hedonic model (equation (1)), our estimate of the MWTP for aquaculture takes the form,

$$
\operatorname{MWTP}\left(Q_{i}\right)=\widehat{\beta}_{3} P_{i}^{1-\widehat{\lambda}}
$$

which is a function of two parameters of the model. The sign and significance of $\widehat{\beta}_{3}$ is sufficient to address our first research question. However, we are also interested in exploring how these marginal impacts vary based on the spatial 
characteristics of mariculture, such as density of leases, acreage of lease, and proximity to residential properties. That is, we are also interested in the MWTP for each component of $Q_{i}$. To this end, we follow the decomposition outlined by Gopalakrishnan and Klaiber (2014), which makes use the total differential of $Q_{i}$ and the chain rule to isolate these margins. ${ }^{7}$ In the following, we will use the base case version of the Aquaculture index to demonstrate.

Based on equation (2), the total differential for $Q_{i}$ takes the form,

$$
d Q_{i}=\sum_{k \in A_{i}} \frac{a_{i k}}{d_{i k}} d K_{i}+K_{i} \sum_{k \in A_{i}} \frac{1}{d_{i k}} d a_{i k}-K_{i} \sum_{k \in A_{i}} \frac{a_{i k}}{d_{i k}^{2}} d d_{i k} .
$$

Equation (3) suggests that the effect of a change in the house-specific Aquaculture index can be decomposed into three pieces: the density effect (holding acreage and proximity constant), the acreage effect (holding the number of aquaculture sites and proximity constant), and the proximity effect (holding the number of aquaculture sites and acreage constant). We use the information from this decomposition to parse out the three margins of interest.

Let $q_{i k}$ denote an attribute of lease $k$ associated with home $i$ (e.g., acreage or distance): one component of $Q_{i}$. The MWTP for attribute $q_{i k}$ is simply

$$
\operatorname{MWTP}\left(q_{i k}\right)=\frac{d P_{i j t}}{d q_{i k}}=\frac{\partial P_{i j t}}{\partial Q_{i}} \frac{\partial Q_{i}}{\partial q_{i k}}
$$

where $\partial Q_{i} / \partial q_{i k}$ can be calculated using equation (3). However, we are not interested in the effect of lease $k$, per se. We are more interested in the "average" marginal effect on house $i$ for a change in attribute $q$ over all the leases that fall within the buffer zone of a home. To this end, we calculate the average marginal effect of a change in $q_{i}$. on house $i$ as,

$$
\operatorname{MWTP}\left(q_{i} .\right)=\frac{1}{K_{i}} \sum_{k \in A_{i}} \operatorname{MWTP}\left(q_{i k}\right) .
$$

\footnotetext{
7 An anonymous referee suggested an alternate, two-stage approach, to ensure that the ceteris paribus assumption holds: In the first stage, use the parameter estimates to predict nonmarginal changes in sales prices (before and after the siting of leases); in the second stage, regress these predicted price changes on the change in the number of leases, lease acreage, and the average distance. Slope estimates from this second stage can be interpreted as a MWTP estimate for the spatial arrangement of leases. Bootstrapping can be performed to ensure that the second-stage standard errors capture the noise from first-stage estimates.
} 
For simplicity, we will refer to this "average" marginal effect as the marginal effect.

Due to the form of $Q_{i}$, we restrict our calculations of $\operatorname{MWTP}\left(Q_{i}\right)$ to the subset of homes that contained aquaculture at the time of sale. For a house that did not originally contain aquaculture, the MWTP is forced to zero by construction of the Aquaculture index.

\section{Results}

The statistical models fit the data well (Table 3). The adjusted $\mathrm{R}^{2}$ values are fairly high, ranging from 0.590 to 0.733 . This, coupled with large model Fstatistics (35.260 to 307.754), suggests that the variables included in the statistical models are jointly relevant and capture most of the variation in housing prices. Finally, all models reject the linear, log-linear, and reciprocal specifications in favor of the Box-Cox transformed models (all p-values are less than 0.015).

All parameter estimates for the structural characteristics, except for the variable Cabin, are statistically significant and have the expected signs. We fail to find evidence that Cabin is significant in Casco Bay. This is unsurprising, as these sales make up less than 0.5 percent of the observed transactions in the Casco Bay housing market. As expected, distance from water negatively impacts housing prices, with this effect dropping off between 2-5 miles from shore. Joint tests suggest this variable is significant across all models. Waterfront properties and those with larger views of water also receive price premiums across all three markets. This supports our expectation that water is perceived as an amenity. In addition, being close to a government-managed or conserved beach, dock, park, or land has a positive impact on prices in all regions except Damariscotta. Finally, our controls for neighborhood characteristics provide mixed results.

\section{Impact of Coastal Aquaculture Production}

We incorporated home-specific information on localized attitudes to separate the effect of neighborhood concerns toward aquaculture, which may depress local property values, from the actual spatial arrangement of leases experienced. Interestingly, we fail to find evidence that Neighborhood attitudes affect property values. This does not mean that these localized attitudes do not matter in coastal real-estate markets; rather, our proxy for this fails to find evidence. This is potentially a limitation of using transcripts from public lease hearings. These hearings only occur for standard leases and some experimental leases (if sufficient comments are made during the public comment period). This bounds the information that we can observe about attitudes, which is compounded by the fact that LPAs, which are more common in these study areas (Table 2), are implicitly assigned zero concerns. 
Table 3. Parameter Estimates from the Box-Cox Hedonic Pricing Model. Sales prices are transformed using the BoxCox transformation parameter $\lambda$. Robust standard errors are reported in parentheses. Parameter estimates for municipality and year fixed effects are available upon request.

\begin{tabular}{|c|c|c|c|c|c|c|}
\hline \multirow{2}{*}{$\begin{array}{l}\text { Control variables } \\
\text { Bathrooms }\end{array}$} & \multicolumn{2}{|c|}{ Casco Bay } & \multicolumn{2}{|c|}{ Damariscotta } & \multicolumn{2}{|c|}{ Penobscot Bay } \\
\hline & $0.324 * * *$ & $0.323 * * *$ & $0.583^{* * *}$ & $0.584 * * *$ & $1.080^{* * *}$ & $1.110^{* * *}$ \\
\hline & $(0.036)$ & $(0.036)$ & $(0.131)$ & $(0.132)$ & $(0.167)$ & $(0.171)$ \\
\hline \multirow[t]{2}{*}{ Living Space $(1,000$ s square feet $)$} & $1.092^{* * *}$ & $1.091^{* * *}$ & $1.247^{* * *}$ & $1.249 * * *$ & $1.338^{* * *}$ & $1.371^{* * *}$ \\
\hline & $(0.033)$ & $(0.033)$ & $(0.139)$ & $(0.140)$ & $(0.221)$ & $(0.226)$ \\
\hline \multirow[t]{2}{*}{ Lot size (100s acres) } & $3.137^{* * *}$ & $3.133^{* * *}$ & $5.604^{* * *}$ & $5.609 * * *$ & $11.074^{* * *}$ & $11.376^{* * *}$ \\
\hline & $(0.580)$ & $(0.579)$ & $(0.686)$ & $(0.687)$ & $(1.563)$ & $(1.602)$ \\
\hline \multirow[t]{2}{*}{ Age (50 years) } & $-0.218^{* * *}$ & $-0.218^{* * *}$ & $-0.270^{* * *}$ & $-0.269^{* * *}$ & $-0.589 * * *$ & $-0.601^{* * *}$ \\
\hline & $(0.023)$ & $(0.023)$ & $(0.051)$ & $(0.051)$ & $(0.076)$ & $(0.078)$ \\
\hline \multirow[t]{2}{*}{ Age squared } & $0.005^{* * *}$ & $0.005^{* * *}$ & $0.004 * * *$ & $0.004^{* * *}$ & $0.012^{* * *}$ & $0.012^{* * *}$ \\
\hline & $(0.001)$ & $(0.001)$ & $(0.001)$ & $(0.001)$ & $(0.002)$ & $(0.002)$ \\
\hline \multirow[t]{2}{*}{ Cabin $(0 / 1)$} & -0.317 & -0.311 & $0.717^{*}$ & $0.714^{*}$ & $1.685^{* *}$ & $1.744^{* *}$ \\
\hline & $(0.250)$ & $(0.249)$ & $(0.368)$ & $(0.369)$ & $(0.783)$ & $(0.810)$ \\
\hline \multirow[t]{2}{*}{ Distance to water (miles) } & $-0.171^{* * *}$ & $-0.171^{* * *}$ & -0.237 & -0.244 & -0.396 & -0.301 \\
\hline & $(0.041)$ & $(0.041)$ & $(0.172)$ & $(0.173)$ & $(0.252)$ & $(0.259)$ \\
\hline \multirow[t]{2}{*}{ Distance sq to water (miles) } & $0.018^{* * *}$ & $0.018^{* * *}$ & $0.067^{* *}$ & $0.068^{* *}$ & $0.112^{* * *}$ & $0.101^{* *}$ \\
\hline & $(0.006)$ & $(0.006)$ & $(0.031)$ & $(0.031)$ & $(0.043)$ & $(0.044)$ \\
\hline \multirow[t]{2}{*}{ View of water (\% 2-mile buffer) } & $2.282^{* * *}$ & $2.289 * * *$ & $3.396^{* * *}$ & $3.397 * * *$ & $5.458 * * *$ & $6.140^{* * *}$ \\
\hline & $(0.141)$ & $(0.142)$ & $(0.473)$ & $(0.474)$ & $(0.751)$ & $(0.789)$ \\
\hline \multirow[t]{2}{*}{ Waterfront $(0 / 1)$} & $1.333^{* * *}$ & $1.333^{* * *}$ & $1.545^{* * *}$ & $1.549 * * *$ & $2.848^{* * *}$ & $2.941^{* * *}$ \\
\hline & $(0.101)$ & $(0.101)$ & $(0.172)$ & $(0.172)$ & $(0.297)$ & $(0.304)$ \\
\hline \multirow[t]{2}{*}{ Govt. Beach/Dock (0/1) } & $0.221^{*}$ & $0.219^{*}$ & 0.118 & 0.115 & $0.865^{* * *}$ & $0.886^{* * *}$ \\
\hline & $(0.121)$ & $(0.121)$ & $(0.269)$ & $(0.270)$ & $(0.309)$ & $(0.316)$ \\
\hline
\end{tabular}


Table 3. Continued

\begin{tabular}{|c|c|c|c|c|c|c|}
\hline \multirow{2}{*}{$\begin{array}{l}\text { Control variables } \\
\text { Elevation (100s feet) }\end{array}$} & \multicolumn{2}{|c|}{ Casco Bay } & \multicolumn{2}{|c|}{ Damariscotta } & \multicolumn{2}{|c|}{ Penobscot Bay } \\
\hline & $-0.101^{* * *}$ & $-0.101^{* * *}$ & $-0.328 * * *$ & $-0.329 * * *$ & 0.029 & 0.038 \\
\hline & $(0.027)$ & $(0.027)$ & $(0.122)$ & $(0.122)$ & $(0.081)$ & $(0.083)$ \\
\hline \multirow[t]{2}{*}{ Seasonal homes ( $\%$ census tract) } & $-0.007^{* *}$ & $-0.007^{* *}$ & -0.024 & -0.025 & -0.068 & -0.087 \\
\hline & $(0.003)$ & $(0.003)$ & $(0.057)$ & $(0.057)$ & $(0.063)$ & $(0.067)$ \\
\hline \multirow[t]{2}{*}{ Median income $^{\dagger}(\$ 10,000 s)$} & 0.004 & 0.005 & $-1.245^{* * *}$ & $-1.241^{* * *}$ & $0.613^{*}$ & $0.639 *$ \\
\hline & $(0.015)$ & $(0.015)$ & $(0.450)$ & $(0.451)$ & $(0.343)$ & $(0.352)$ \\
\hline \multirow[t]{2}{*}{ Spending per student $(\$ 1,000 s)$} & 0.048 & 0.049 & 0.043 & 0.042 & $0.141^{*}$ & $0.136^{*}$ \\
\hline & $(0.032)$ & $(0.032)$ & $(0.049)$ & $(0.049)$ & $(0.073)$ & $(0.074)$ \\
\hline \multirow[t]{2}{*}{ Sale in winter $(0 / 1)$} & $-0.144^{* * *}$ & $-0.144 * * *$ & -0.065 & -0.067 & -0.054 & -0.060 \\
\hline & $(0.041)$ & $(0.041)$ & $(0.149)$ & $(0.149)$ & $(0.195)$ & $(0.201)$ \\
\hline \multirow[t]{2}{*}{ Constant } & $19.804^{* * *}$ & $19.778 * * *$ & $29.587^{* * *}$ & $29.613 * * *$ & $25.349 * * *$ & $25.787^{* * *}$ \\
\hline & $(0.203)$ & $(0.203)$ & $(2.639)$ & $(2.643)$ & $(1.852)$ & $(1.916)$ \\
\hline \multicolumn{7}{|c|}{ Aquaculture Variables and Transformation Parameter } \\
\hline \multirow[t]{2}{*}{ Neighborhood attitudes } & -0.005 & 0.012 & -0.778 & -0.770 & 0.000 & -0.061 \\
\hline & $(0.058)$ & $(0.055)$ & $(0.512)$ & $(0.512)$ & $(0.335)$ & $(0.336)$ \\
\hline \multirow[t]{2}{*}{ Aquaculture index (base) } & -0.885 & & $0.694^{* * *}$ & & $-23.392 * *$ & \\
\hline & $(2.922)$ & & $(0.215)$ & & $(10.882)$ & \\
\hline \multirow[t]{2}{*}{ Aquaculture index (alternate) } & & -7.894 & & $4.342^{* * *}$ & & $-57.609 * *$ \\
\hline & & $(9.837)$ & & $(1.367)$ & & $(24.721)$ \\
\hline \multirow[t]{2}{*}{ Transformation parameter $(\lambda)$} & $0.100 * * *$ & $0.099 * * *$ & $0.110^{* *}$ & $0.111^{* *}$ & $0.141^{* * *}$ & $0.143^{* * *}$ \\
\hline & $(0.010)$ & $(0.010)$ & $(0.022)$ & $(0.022)$ & $(0.017)$ & $(0.017)$ \\
\hline Number of observations & 5698 & 5698 & 1238 & 1238 & 1644 & 1644 \\
\hline Adjusted $\mathrm{R}^{2}$ & 0.733 & 0.733 & 0.598 & 0.598 & 0.590 & 0.590 \\
\hline F-statistics (Wald) & 307.754 & 307.968 & 39.255 & 39.200 & 35.260 & 35.568 \\
\hline
\end{tabular}

${ }^{\dagger}$ Median household income $(\$ 10,000 s)$ in the home's census tract.

Significance levels: ${ }^{* * *} \mathrm{p}<0.01,{ }^{* *} \mathrm{p}<0.05$, and ${ }^{*} \mathrm{p}<0.10$ 
We find more interesting patterns related to the Aquaculture index, which captures the spatial arrangement of leases in relation to a home. Our results suggest variation in the impact on housing prices across the three regions. We fail to find evidence of any impact in Casco Bay, while we find statistically significant evidence for the other study areas. This pattern is robust to our specification of the Aquaculture index (base and alternate form). It is difficult to directly compare the magnitude of coefficients across models, as each is transformed using a different value for the Box-Cox transformation parameter. Instead, the following focuses on differences in sign and significance across regions.

For example, Aquaculture index is significant and positive for the Damariscotta River region. That is, after controlling for structural and neighborhood characteristics, and attitudes surrounding aquaculture, houses with "more" coastal aquaculture command a higher price on average, suggesting that aquaculture may be viewed as an amenity in the region. In Penobscot Bay, we find the opposite result, with coastal aquaculture lowering sales prices - coastal aquaculture may be viewed as a disamenity in this housing market. This pattern is consistent with the information on concerns raised at public lease hearings (Table 2). Note that, on average, there are more than twice as many concerns raised about the development of mariculture and how it affects riparian homeowners and coastal users in Penobscot Bay.

Given the evidence that aquaculture capitalizes into residential property values in two study areas, we explore the relative magnitude of these marginal impacts - are they large or small in these study areas? That is, while statistically significant, are these results economically significant? A comparison of the marginal effects for the components of the Aquaculture index will provide insight into this,and answer our second research question. Based on the design of this index, there are three margins of interest: the density effect, the acreage effect, and the proximity effect (equation 3). The density effect measures the marginal impact of an additional lease sited near a home, holding the number of acres of aquaculture production and proximity constant. ${ }^{8}$ The acreage effect and proximity effect have similar interpretations. Given the Box-Cox transformation and the form of the Aquaculture index, these margins are nonlinear and depend on a combination of parameter estimates, the Box-Cox transformation parameter, and, importantly, the sales price of a home; this generates heterogeneity in the marginal impacts across the sample. We calculate margins at the house-level using sample values. Further, we restrict attention to houses with aquaculture sited within a 2-mile buffer zone of the home. Given skewness in prices (evident from the estimates of the Box-Cox transformation parameter),

8 This is similar in theme to the expected contribution of an additional bedroom, ceteris paribus, to the sales price of home, which holds square footage of the home constant. 
the margins will also be skewed, creating larger marginal effects on more expensive homes. To address skewness, we focus on measures of the median marginal impact. See Section 3.3 for more details on calculation of these margins.

Table 4 depicts the median MWTP for our sample by study area and model: including the density effect, acreage effect and proximity effect. In all cases, the median MWTP is smaller (in absolute value) than the average MWTP (not shown), suggesting a long tail to the house-level distribution of marginal impacts - as expected, given the skew in prices. There are significant differences in the scale of marginal effects across regions. For example, the median MWTP for an increase in the density of aquaculture leases (its implicit marginal price) in the Damariscotta River region range from $\$ 2$ to $\$ 4$ (across models) but are much larger and negative in Penobscot Bay $(-\$ 1,006$ to $-\$ 1,589$ ). Similar patterns exist for increasing the acreage of aquaculture and moving leases closer to homes, with the median marginal impacts being larger and negative in Penobscot Bay: between $-\$ 638$ and $-\$ 705$ per acre and $-\$ 0.44$ and $-\$ 0.78$ per meter, respectively. Given the different units of measure for these components, it is difficult to make comparison across effects (e.g., proximity versus acreage). The smaller marginal impact on proximity should not be inferred as smaller effect.

While statistically significant, the magnitude of the sample MWTPs for the Damariscotta River region suggest they are not economically significant. That is, relative to the sales price of a home, the MWTPs in this study area are inconsequentially small: the median MWTP was less than 0.01 percent of the sales price of a home across all margins and models. As such, the following focuses on the larger MWTP estimates from Penobscot Bay. In the base model, 95 percent of the sample estimates of the density effect, i.e., the MWTP for an additional lease near a home, correspond with a reduction in sales price of a home between less than 0.01 percent (very small) and 4.71 percent (much larger). Within this sizable range of impacts, the median loss is only 1.06 percent of the sales price. Similar patterns exist for increasing acreage and reducing proximity. In the alternate model, adjusting the Aquaculture index to control for the portion of water in the buffer zone, our median loss is smaller (0.51 percent), though the 95-percent interval is largely unchanged (between less than 0.01 percent to 4.39 percent).

\section{Discussion}

Marine aquaculture could grow to be an important component of the "blue economy" for the United States. It has the potential to help satisfy growing demand for fish protein, reduce the U.S. seafood trade deficit, create healthier oceans, and provide localized benefits to coastal communities. Despite the potential economic and ecological benefits from expanding coastal aquaculture, its expansion will alter the mixture of winners and losers, potentially creating tensions among coastal resource users, regulators, 
Table 4. Median Marginal Willingness-to-Pay (MWTP) (\$) for coastal aquaculture by study area and model. Estimates calculated from the subset of observations that contained aquaculture within a 2-mile buffer zone. Density depicts the margin for an additional lease holding the number of acres and distance of leases to houses constant - increasing the density of leases contained in the existing acreage. Acreage depicts the margin for an additional acre of aquaculture, holding the number of leases and distance from housing constant. Proximity depicts the margin for moving 1 meter closer to aquaculture holding the number of leases and acres constant. One-tailed p-values simulated using 100,000 draws from the parameters estimates (Table 3).

\begin{tabular}{llccc}
\hline Study area & Model & Density & Acreage & Proximity \\
\hline \multirow{2}{*}{ Casco Bay } & Base & -39.64 & -54.71 & -0.01 \\
& Alternate & -122.62 & -228.04 & -0.05 \\
Damariscottta & Base & $1.69^{* * *}$ & $93.77^{* * *}$ & $0.01^{* * *}$ \\
& Alternate & $3.59^{* * *}$ & $156.05^{* * *}$ & $0.01^{* * *}$ \\
Penobscot Bay & Base & $-1,588.79^{* *}$ & $-704.57^{* *}$ & $-0.78^{* * *}$ \\
& Alternate & $-1,006.27^{* * *}$ & $-637.75^{* * *}$ & $-0.44^{* * *}$ \\
\hline
\end{tabular}

Significance levels: ${ }^{* *} \mathrm{p}<0.01,^{* *} \mathrm{p}<0.05$, and ${ }^{*} \mathrm{p}<0.10$ 
government agencies and other invested stakeholders (e.g., NGOs) (Knapp 2012, Knapp and Rubino 2016). Researchers argue that we could reduce these tensions through improved availability of interdisciplinary research and communication of the positive benefits of aquaculture to these groups of users (Bricknell and Langston 2013, NOAA 2016b). These challenges highlight the importance of acceptance by coastal resource users for the successful expansion of mariculture. Resource managers and regulators with a deeper understanding of the impacts of marine development (e.g., mariculture) could design spatial plans that balance concerns across a suite of users and promote this emerging industry. To this end, quantifying the impacts of mariculture development on coastal residential property values provides resource managers with valuable information for integrative marine spatial planning.

This paper presents an important addition to the literature and provides one of the first empirical analyses of the effect of marine aquaculture on coastal, residential property values. This revealed-preference study complements the stated-preference work on public perceptions toward aquaculture (Shafer, Inglis, and Martin 2010, D’Anna and Murray 2015, Jodice et al. 2015). Further, the design of our hedonic model allows us to address questions of direct interest to policy makers and land managers regarding the development of mariculture. Specifically, we measure not just the impact from proximity to aquaculture, but also from the spatial configuration of its siting, e.g., the density and acreage of leases across the local seascape. The results from this work provide insights into the impact of decentralized expansion of marine aquaculture. Finally, our results can also inform future exploratory analyses of transcripts from aquaculture lease hearings. For example, an exploration of the patterns of concerns raised at these hearings, and how they vary by lease, lessee, and community characteristics could be important for coastal managers. This type of analysis could provide information about the efficacy of public participation in the siting process, as well as provide insight into designing a siting framework that improves social acceptance of mariculture.

While there is a rich body of work that has evaluated the impact of land-based farming (Abeles-Allison and Connor 1990, Palmquist, Roka, and Vukina 1997, Le Goffe 2000, Herriges, Secchi, and Babcock 2005, Ready and Abdalla 2005, Kim and Goldsmith 2009), few studies have attempted to investigate the impact of water-based farming on residential property values (Northern Economics 2010, Jodice et al. 2015, Sudhakaran 2015). Our work fills this hole in the research. Our results suggest wide variation in how marine development of aquaculture impacts property values, both across and within study areas. In Casco Bay, we fail to find statistical evidence of impacts from marine aquaculture. Recall that this is an urban area for Maine, with an active working waterfront for shipping, recreation, and commercial fishing. It is possible that mariculture is insubstantial relative to these other coastal uses. In the Damariscotta River region, we find statistically significant and positive effects of the development of marine aquaculture. However, these 
effects are very small - economically insignificant. This region has a long history of promoting aquaculture in its waters (Damariscotta River Association 2016). Our results may suggest that these efforts have been largely successful so that mariculture "blends" into the seascape. Finally, in Penobscot Bay, we find both statistically and economically significant negative impacts. Within this region, property values tend to fall as aquaculture leases become larger, denser, and closer to coastal homeowners. There is considerable within-sample variation of these impacts. Ninety-five percent of the observed transactions that had aquaculture within two miles experienced reductions in sales price from as low as less than 0.01 percent to as high as 4.7 percent (base model). For the past 40 years, this region has grown dependent on ecotourism for its income, relying on the natural quality of its environment (Penobscot Marine Museum 2012). Marine aquaculture could appear intrusive to the perception of this natural environment. This would be consistent with past research (Shafer, Inlgis, and Martin 2010, D'Anna and Murray 2015).

Despite the results that property values in two study areas are unaffected by the current level of mariculture, this does not suggest that we should target development in these areas. The hedonic model limits us to insights about the effect of development on the margin - household location choices are fixed. If we are to achieve the level of development suggested by NOAA's target (50-percent increase in marine production by volume), then this would require large-scale, nonmarginal change in our coastal waters, which may lead to substantially different results. For example, it is possible that while a marginal increase in development of mariculture may reduce property values in Penobscot Bay, large-scale development may increase property values if it generates sufficient increases in local incomes through direct and indirect economic spillovers. While understanding the effects of nonmarginal development is important, it is beyond the scope of this paper. Future work should consider incorporating estimators capable of predicting nonmarginal impacts (e.g., equilibrium sorting models or other structural equation models). An important component of this work should be identifying the mechanisms through which aquaculture affects property values and the distance at which these effects become negligible.

It is also unlikely that the uncoordinated development of marine aquaculture will balance productive (e.g., profitable) growing of marine-based food with the spatial variation of social acceptance. Instead, we may want to consider adjustments to the leasing process to improve our awareness of these potential tradeoffs. For example, if the state wants to maintain control over the leasing process, it may consider the use of marine aquaculture zones. These predefined lease areas could be evaluated for biological productivity and social acceptance, coordinating development along the coastline. Alternatively, fine-scale management may also be successful. A potential candidate would be a co-managed process with municipalities, similar to how Maine currently co-manages its soft-shell clam fishery, giving municipalities power to govern access, fishing effort, and conservation activities in coastal 
waters. This would allow leasing to capture the spatial heterogeneity of preferences across the coastline, and designate acceptable lease areas.

Our work reveals interesting challenges for coastal resource managers. There are potential benefits from coordinating aquaculture siting decisions to balance the competing objectives of diverse groups of coastal resource users. Policy makers could find this information especially relevant when considering future development of aquaculture and coastal planning as coastal development continues to accommodate growing populations and aging communities. Questions about the scale of coastal development are becoming more pressing as coastal populations grow (NOAA 2013). This requires information on preferences from multiple groups of users, which is often costly and difficult to obtain. The results from our hedonic pricing model aid to fill knowledge gaps for these managers, providing information on preferences toward the development of aquaculture in coastal waters by one particular group of users, coastal residents. It is possible that although an area may be biologically suitable for aquaculture development, failure to consider the social suitability of siting decisions could lead to unintended consequences that slow the long-run development of marine aquaculture. Our findings provide empirical evidence that mariculture sometimes exerts an externality that is often overlooked, but not always. Thus, it is worthwhile for both stakeholders and policy makers to carefully consider the impacts. Future planning and development can use these results and insights to inform integrative coastal management.

\section{Supplementary Material}

To view supplementary material for this article, please visit https://doi.org/10. 1017/age.2017.19.

\section{References}

Abeles-Allison, M., and L.J. Connor. 1990. "An Analysis of Local Benefits and Costs of Michigan Hog Operations Experiencing Environmental Conflicts." Agricultural Economic Report Series 201396, Department of Agricultural, Food, and Resource Economics, Michigan State University, East Lansing, MI.

Bhat, M., and R. Bhatta. 2004. "Considering Aquacultural Externality in Coastal Land Allocation Decisions in India." Environmental and Resource Economics 29(1): 1-20.

Bohlen, C., and L.L. Lewis. 2009. "Examining the Economic Impacts on Hydropower Dams on Property Values using GIS." Journal of Environmental Management 90(3): S258-S269.

Box, G.E.P., and D.R. Cox. 1964. "An Analysis of Transformations." Journal of the Royal Statistical Society 26(2): 211-252.

Bricknell, I., and A. Langston. 2013. "Aquaculture: It's Not All About Atlantic Salmon." Journal of Fisheries and Livestock Production 1(1): 41-72.

Claret, A., L. Guerrero, R. Gines, A. Grau, M. Hernandez, E. Aguirre, J. Peleteiro, C. FernandezPato, and C. Rodriguez-Rodriguez. 2014. "Consumer Beliefs Regarding Farmed Versus Wild Fish." Appetite 79: 25-31. 
Damariscotta River Association. River Facts. Available at www.damariscottariver.org/aboutus/river-facts / (accessed May 12, 2016).

D’Anna, L.M., and G.D. Murray. 2015. "Perceptions of Shellfish Aquaculture in British Columbia and Implications for Well-Being in Marine Social-Ecological Systems." Ecology and Society 20(1): 57-68.

East Coast Environmental Law. 2014. "Comparative Analysis of Aquaculture Regulatory Frameworks in Maine and Nova Scotia." Report for the Doelle-Lahey Panel: Independent Aquaculture Regulatory Review for Nova Scotia.

Food and Agriculture Organization of the United Nations. 2016. "The State of World Fisheries and Aquaculture 2016: Contributing to Food Security and Nutrition for All." Technical Report. Rome.

Gericke, K.L., and J. Sullivan. 1994. "Public Participation and Appeals of Forest Service Plans An Empirical Examination." Society and Natural Resources 7(2): 125-135.

Gibbs, J., J. Halstead, K. Boyle, and J. Huang. 2002. "An Hedonic Analysis of the Effects of Lake Water Clarity on New Hampshire Lakefront Properties." Agricultural and Resource Economics Review 31(1): 39-46.

Gopalakrishnan, S., and H.A. Klaiber. 2014. "Is the Shale Energy Boom a Bust for Nearby Residents? Evidence from Housing Values in Pennsylvania." American Journal of Agricultural Economics 96(1): 43-66.

Graves, L. 2016. “Oyster farm drawing fire.” Mount Desert Islander, August 4.

Griliches, Z. 1971. "Hedonic Price Indexes of Automobiles: An Econometric Analysis of Quality Change." In Z. Griliches, ed., Price Indexes and Quality Change. Cambridge: Cambridge University Press.

Herriges, J.A., S. Secchi, and B.A. Babcock. 2005. "Living with Hogs in Iowa: The Impact of Livestock Facilities on Rural Residential Property Values. Land Economics 81(4), 530545.

Jodice, L.W., W.C. Norman, J. Davis, G. Coskun, and S. Kang. 2015. "Perceptions of Marine Aquaculture in Coastal Tourist Destinations in the US Southeastern Region." Technical Report. Clemson University - South Carolina Sea Grant, Clemson, SC.

Kapetsky, J., J. Aguilar-Manjarrez, and J. Jenness. 2013. "A Global Assessment of Offshore Mariculture Potential from a Spatial Perspective." FAO Fisheries and Aquaculture Technical Paper 549. Food and Agriculture Organization of the United Nations. Rome.

Kim, J., and P. Goldsmith. 2009. "A Spatial Hedonic Approach to Assess the Impact of Swine Production on Residential Property Values." Environmental and Resource Economics 42 (4): 509-534.

Kite-Powell, H.L., M.C. Rubino, and B. Morehead. 2013. "The Future of US Seafood Supply." Aquaculture Economics and Management 17(3): 228-250.

Knapp, G. 2008. "Offshore Aquaculture in the United States: Economic Considerations, Implications and Opportunities." In M. Rubino, ed., Economic Potential of US Offshore Aquaculture. NOAA Technical Memorandum NMFS F/SPO-103.

_ 2012. "The Political Economics of United States Marine Aquaculture." Bulletin of the Fisheries Research Agency. 35: 51-63.

Knapp, G., and M.C. Rubino. 2016. "The Political Economics of Marine Aquaculture in the United States." Reviews in Fisheries Science and Aquaculture 24(3): 213-229.

Lapointe, G. 2013. "Overview of the Aquaculture Sector in New England" Northeast Regional Ocean Council White Paper.

Le Goffe, P. 2000. "Hedonic Pricing of Agriculture and Forestry Externalities." Environmental and Resource Economics 15(4): 397-401.

Lewis, L.L., C. Bohlen, and S. Wilson. 2008. "Dams, Dam Removal, and River Restoration: A Hedonic Property Value Analysis." Contemporary Economic Policy 26(2): 175-186.

Maine Aquaculture Association (MAA). 2015. Maine aquaculture snapshot. Available at http://www.maineaquaculture.com/Publications/FactCardsingle.pdf (Accessed March 20, 2016). 
Maine Coastal Program. 2013. Maine Coastal Zone Map. Available at http://www.maine.gov/ $\mathrm{dacf} / \mathrm{mcp} /$ about/coastalzonemap.htm (Accessed December 28, 2015).

Maine Department of Marine Resources. n.d. Aquaculture in Maine. Available at http://www. maine.gov/dmr/aquaculture/ (Accessed October 4, 2015).

—, 2016. Maine Aquaculture Harvest Data. Available at http://www.maine.gov/dmr/ aquaculture/harvestdata/index.html (Accessed October 4, 2015).

Maine Revised Statutes Annotated (MRSA) 12, Chapter 2. 2013. Aquaculture Lease Regulations. Available at http://www.maine.gov/dmr/laws-regulations/regulations/ documents/0202_101713.pdf (Accessed October 30, 2015).

Mazur, N.A., and A.L. Curtis. 2008. "Understanding Community Perceptions of Aquaculture: Lessons from Australia." Aquaculture International 16(6): 601-621.

McCluskey, J.J., and G.C. Rausser. 2001. "Estimation of Perceived Risk and its Effect on Property Values." Land Economics 77(1): 42-55.

McGinnis, M.V., and M. Collins. 2013. "A Race for Marine Space: Science, Values, and Aquaculture Planning in New Zealand." Coastal Management 41(5): 401-419.

Michael, H., K. Boyle, and R. Bouchard. 2000. "Does the Measurement of Environmental Quality Affect Implicit Prices Estimated from Hedonic Models?" Land Economics 79(2): 283-598.

Mitterhoff, M. 2016. “Hearing on mussel farm lease to resume." Mount Desert Islander, January 16.

Muehlenbachs, L., E. Spiller, and C. Timmins. 2015. "The Housing Market Impacts of Shale Gas Development." American Economic Review 105(12): 3633-3659.

National Oceanic and Atmospheric Administration (NOAA). 2013. "National Coastal Population Report: Population trends from 1970 to 2020." NOAA's State of the Coast Report Series. National Oceanic and Atmospheric Administration, Washington, DC. Available at http://oceanservice.noaa.gov/facts/coastal-population-report.pdf (Accessed August 27, 2016).

- 2015. "Imports and Exports of Fishery Products: Annual Summary, 2014 Revised." Technical Report. Current Fishery Statistics NO. 2014-2, National Oceanic and Atmospheric Administration, Washington, DC.

- 2016a. Aquaculture in the United States. Available at http:///www.nmfs.noaa.gov/ aquaculture/aquacultureaquaculture_inin_us.html (Accessed July 11, 2016).

— National Oceanic and Atmospheric Administration (NOAA), Washington, DC. Available at http://www.nmfs.noaa.gov/aquaculture/docs/aquaculture_docs/noaa_fisheries_marine_ aquaculture_strategic_plan_fy_2016-2020.pdf (Accessed July 11, 2016).

Maryland Natural Resources Code §4-11A-05. 2015. Chesapeake Bay - Aquaculture Enterprise Zone. Available at http://law.justia.com/codes/maryland/2015/article-gnr/ title-4/subtitle-11a/section-4-11a-05/ (Accessed August 15, 2016).

Northern Economics. 2010. "Technical Memorandum: Property Value Study - NOAA Marine Aquaculture Grant." Technical memorandum. Anchorage, AK.

Palmquist, R.B., F.M. Roka, and T. Vukina. 1997. "Hog Operations, Environmental Effects, and Residential Property Values." Land Economics 73(1): 114-124.

Penobscot Marine Museum. 2012. Working the Bay. Available at http://www. penobscotmarinemuseum.org/pbho-1/working-the-bay/changes-industries-and-risetourism (Accessed May 11, 2016).

Poor, P., K. Pessagno, and R. Paul. 2007. "Exploring the Hedonic Value of Ambient Water Quality: A Local Watershed-based Study.” Ecological Economics 60(4): 797-806.

Primavera, J. 2006. "Overcoming the Impacts of Aquaculture on the Coastal Zone." Ocean and Coastal Management 49(9-10), 531-545.

Ready, R.C., and C.W. Abdalla. 2005. "The Amenity and Disamenity Impacts of Agriculture: Estimates from a Hedonic Pricing Model." American Journal of Agricultural Economics 87(2): 314-326. 
Rosen, S. 1974. "Hedonic Prices and Implicit Markets: Product Differentiation in Pure Competition." Journal of Political Economy 82(1): 34-55.

Schlag, A. 2010. "Aquaculture: An Emerging Issue of Public Concern." Journal of Risk Research 13(7): 829-844.

Shafer, C.S., G.J. Inglis, and V. Martin. 2010. “Examining Residents' Proximity, Recreational Use, and Perceptions Regarding Proposed Aquaculture Development." Coastal Management 38(5): 559-574.

Sudhakaran, P.O. 2015. "Three essays on shellfish management in Rhode Island." Ph.D. dissertation, Department of Environmental and Natural Resource Economics, University of Rhode Island.

Sustainable Ecological Aquaculture Network. 2016. SEANET Research. Available at https:// umaine.edu/seanet/research (Accessed November 03, 2015).

Governor's Task Force on the Planning and Development of Marine Aquaculture in Maine. 2004. "Governor's Task Force on the Planning and Development of Marine Aquaculture in Maine - Executive Summary of Final Report." Marine Resources Documents 8. Augusta, ME.

Valderrama, D., and J. Anderson. 2008. "Interactions Between Capture Fisheries and Aquaculture." In M. Rubino, ed., Economic potential of US offshore aquaculture. NOAA Technical Memorandum NMFS F/SPO-103.

Whitmarsh, D., and M. Palmieri. 2008. "Aquaculture in the Coastal Zone: Pressures, Interactions and Externalities." In M. Holmer, K. Blackm, C.M. Duarte, N. Marba, and I. Karakassis, eds., Aquaculture in the Ecosystem. Springer Science and Business Media.

World Bank. 2013. "Fish to 2030: Prospects for Fisheries and Aquaculture." Agriculture and Environmental Services Discussion Paper \#03, World Bank Report \#83-177-GLB, Washington, DC. 